\title{
佐賀県北部山間地におけるリンゴ病害虫の発生実態と ポリオキシン耐性斑点落葉病菌の出現
}

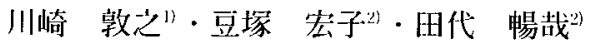

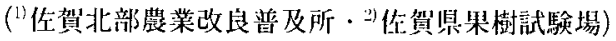

\begin{abstract}
Major diseases and insect pests of apple in the northern highlands of Saga Prefecture and occurrence of polyoxin-tolerant isolates of Alternaria alternata apple pathotype. "Nobuyuki KAWASAKI, "Hiroko MAMETSUKA and "Nobuya TASHIRo (" Saga North District Agriculture Extension Office, Mitsuze, Saga 842-03. 2) Saga Fruit Tree Experiment Station, Ogi, Saga 845)
\end{abstract}

It was revealed by a field survey that apples cultured in the northern highlands of Saga Prefecture were heavily damaged by early leaf drop caused by alternaria leaf spot (Alternaria alternata apple pathotype) and leaf blotch (Diplocarpon mali). The leaf spot occurred at the beginning of the rainy season in June and the cultivar 'Fuji' was severly affected by these diseases. The strong tolerance of the strain of Alternaria alternata apple pathotype to polyoxin, a fungicide for control of the disease, was found in one orchard of the eleven orchards surveyed. On the other hand, the intermediate strains were found in ten orchards. Leaf blotch rapidly increased in the middle of the fruit growing season. In addition to the diseases mentioned above, scab (Venturia inaequalis) and gray mold (Botrytis cinerea) also occurred in several orchards.

Leaves, flower buds and young fruits were infested with aphids, weevils, leaf rollers and caterpillars at flowering and fruit-setting periods. After the end of July, aphids, leafrollers, fruit moth larvae and apple leafminer occurred.

佐賀県の北部山間地では, 観光農業の目玉王として 7 年 前にリンゴ栽培が導入され，現在11戸の農家が 3 町村で 7 ha の観光りんご園を経営している。しかし, 導入後 の年数が浅いことから，栽培上の問題点もまだ多く残さ れている。とくに，梅雨明け頃からみられる早期落菓に よる結実不良や樹勢衰弱は，生産上大きな不安定要因に なっており，その早急な解決が望まれている。しかし， 現在では早期落葉の主因と考えられる病害虫の発生消長 およびその被害の春態については明らかになっていない。

そこで本研究では，りんご栽培の安定化を図る目的か ら、この地域におけるリンゴ病害虫の発生消長を調査し， さらに, 主要病㕩である斑点落葉病の防除薬殽として㕕 く用いられているポリオキシン骩に対して，耐性菌の出 現が瞐念されるリンゴ園から菌の分離を行い, 本薬戍に 対する耐性の有無について検定を行った。これらの結果, 若干の知見が得られたのでここに報告する。

なお，現地調査にあたり御協力いただいた传賀北部農 業技術者連絡協議会の各位，ならびにリンゴ害虫につい

\footnotetext{
1)現在 武雄業農業改良普及所
}

て種々御助言いただいた佐賀県果樹試験場村岡実特別研 究員に詨し、感謝の意を表する。

\section{調査方 法}

\section{1，病害虫の発生消長}

佐賀県佐賀郡富上町ならびに神埼郡三瀬村の 6 園地に ついて,リンゴの巡回調查実施方法 ${ }^{1}$ に基づき各種病害 虫の発生状況を詷查した。調查は萌芽直徯の1989年 4 月 中旬に開始し, 早生種収穫終了後の 9 月下旬まで行った。 1 園につき, 早生種として つがる’，晚生種として‘ 心゙の2品種をそれぞれ3樹供試し，各樹25本の新梢に ついて10日間隔で調査をした。なお，7月中句以降は新 梢の伸長が停止するため，徤長枝25本について同様の調 查を行った。

\section{2、斑点落葉病菌のポリオキシン剤に対する 感受性検定}

富上町，三濑村ならびに神埼郡金振村のリンゴ栽培農 家11巨の園から，斑点落葉病の䍜病葉を 6 月10日，7月 22日および9月12日の3回にわたり採集し，その病原菌 を装寒天培地を用いて単菌系分離を行った。これらの分 


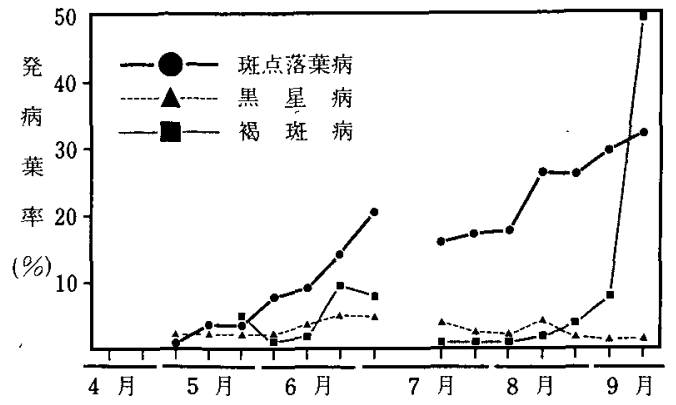

第1図リンゴ(品種ふじ) における各種满害の発生推移

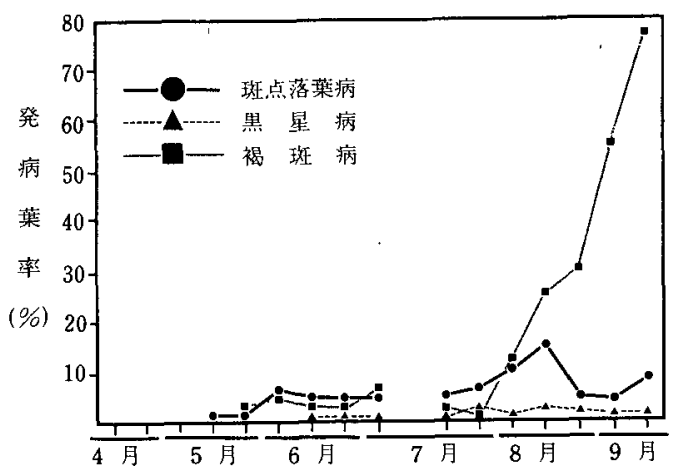

第2図 リンゴ（品種つがる）における各種病害の発生推移

離菌株をPSA 培地で 4 日間前培養し。菌そう周辽部を 直径 $4 \mathrm{~mm}$ のコルクボーラーで打ち抜いて接種源とし，ポ リオキシン 200ppm 添加 PSA 培地と無添加 PSA 培地 に接種した。2 $5^{\circ} \mathrm{Cで} 3$ 日間培養後, それぞれの菌そう直 径を測定し，耐性程度を判定した。すなわち，菌そう生 育率 $(\%)$ を下記の式によって求为，菌そう生育率の $0 \%$ 感受性菌，1～75\%を中等度耐性菌，76一100\% を高度耐性菌とした。

菌そう生育率= $\mathrm{B} / \mathrm{A} \times 100(\%)$
A：無添加区菌そう直佳一接種源直径
$B ：$ 添加区菌そう直径一接種源直径

\section{結果}

\section{1. 病害虫の発生消長}

佐賀県北部山間地域のリンゴ産地における主要病害と して, 斑点落葉病 (Allernaria alternata apple pathotype), 黒星病 (Venturia inaequalis) および褐斑病（Diplocarpon mali) の発生が確認された。これらの発生消長を示した のが第 1 図打よび第 2 図である。

斑点落葉病は品種間による発生の違いが明らかであっ

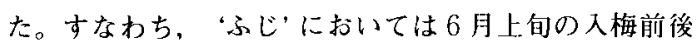

より発生が急激に増加し，7月にはいると発病葉の落葉 が始まり，本品種における早期落葉の主要な原因になっ ていた。7月以降も発生は增加し，9月28日の最終調查 時には，徒長枝葉に打ける平均発病葉率は31.7\%に達し た。こ机に対してつがるでは本病の発生は著しく少 なく, 最高発病葉率は 8 月18日の $15.4 \%$ で，本病による 落葉はほとんど観察されなかった。

褐斑病は雨品種とも7月まではあまり発生がみられな かったが、つがる゙では 8 月上句から， ふじでは8 月下旬加急增した。9月には発病葉率100\%の固もみ られ，本病は雨品種ともに生育徯期における落葉の主因 となっていた。

黒星病は大部分の調查園で発生を認めなかったが，1 生産闷地で多発した。この発病園では，6月中旬以降の 雨により急激に被害が坛がり，本病による落葉も認めら 机た。

この他，5月中句に灰色かび病（Botrytis cinerea）の罹 病花茾が葉身に落ちて，その発生が若干みられたが，そ の他のリンゴの主要病害とされているモニリア病 (Monilinia mali), うどんこ病 (Podosphaera leucotricha), 赤星病 (Gymnosporangum yamadae), 腐 $ら ん$ 病 (Valsa ceratosperma）などの発生は本年の調査では確認されなか った。

次に，主要害虫 3 種によるリンゴ梢葉の被害率の推移 を第 1 表に示した。八マキムシ類の発生は，6月上旬ま での生育前物と 9 月下旬にみられた。とくに, 開花前の 4 月中句には被慧花そう率が10\%に達した園もあり，葉

第 1 表 3 種堙虫によるリンゴ梢葉の铍害率の推栘

\begin{tabular}{|c|c|c|c|}
\hline 調查月日 & ハマキムシ & キンモンホソガ & アブラムシ \\
\hline 4月17日 & 3.7 & & 3.9 \\
\hline 25日 & & & 13.4 \\
\hline 5 月9日 & 0.3 & & 18.5 \\
\hline 18 日 & & & 1.4 \\
\hline 29日 & 0.3 & 0.1 & \\
\hline 6 月 8 日 & 03 & & 0.3 \\
\hline 19日 & & 0.1 & 1.2 \\
\hline \multicolumn{4}{|l|}{$29 日$} \\
\hline 7 月 8 日 & & 0.1 & 2.8 \\
\hline 20 日 & & 0.2 & 9.2 \\
\hline 31 日 & ' & & 5.0 \\
\hline 8 月 10 日 & & 0.3 & 3.5 \\
\hline \multicolumn{4}{|l|}{$18 \mathrm{H}$} \\
\hline 29日 & & 1.1 & 2.4 \\
\hline 9 月12日 & & 2.3 & 0.6 \\
\hline $28 \mathrm{E}$ & 0.3 & 0.7 & . \\
\hline
\end{tabular}

注）ハマキムシとアブラムシは被害新梢率（\%) キンモンホソガは被管葉率 (\%) 
と花蕾に食害がみられた。

キンモンホソガ (Phyllonorycter ringoniella) は5 月下旬 から発生がみられ，8月下旬から9月上旬にかけて被害

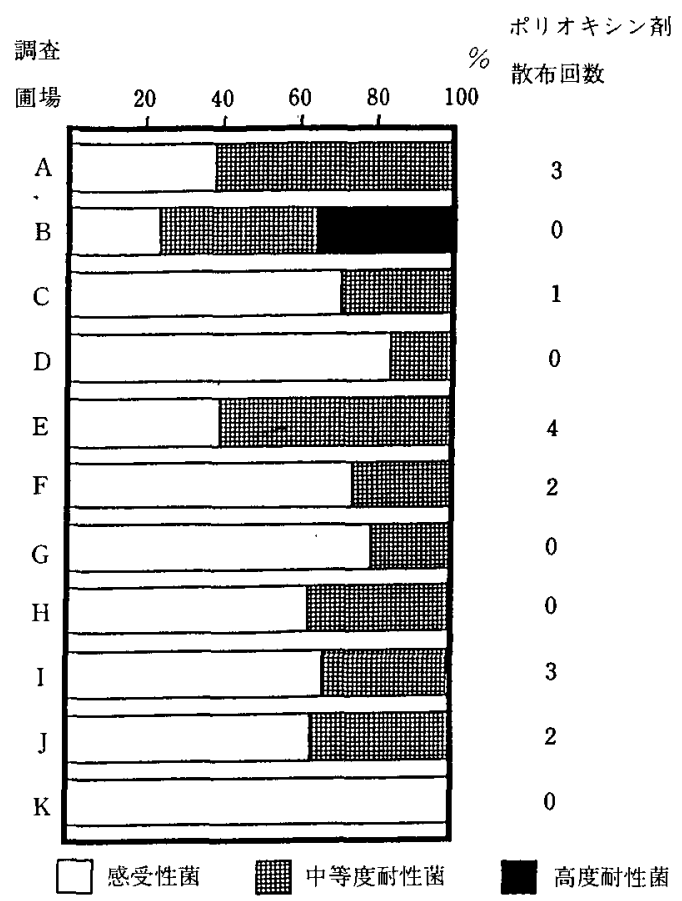

第3図ポリオキシン而性斑点落葉病菌の分離状況
葉率が增㞦し，樹勢の溻し樹では落葉を助曼した。

アブラムシ類は調查を開始した 4 月中旬から発生がみ られ，被害新梢率も高く，5月9日には18.5\%に達した。

この他の管虫として，ゾウムシ類ではモモチョッキリ ゾウムシ (Rhynchites heros) とキュウシュウヒゲボソゾウ ムシ (Phyllobius rotundicollis) が，開花期前後に花蕾，幼 果を食㕩した。シャクトリムシ類は 5 月上旬，8月中〜 下够に葉を食害，シンクイムシ類が 8 月中〜下旬に徒長 枝の心折れの被㕩を抗こした。ハダニ類ではリンゴハダ 二 (Panonychus ulmi) が 5 月中旬， 8 月中旬 9 月下旬に, ナミ八ダニ (Tetranychus urticae) が 7 月下旬 -8 月中旬に 発生した。訪花昆虫は開花期前後にコアオハナムグリ (Oxycetonia jucunda) の発生を確認した。

\section{2、ポリオキシン剤而性斑点落葉病菌の出現}

管内11戸の農家のリンゴ園における1989年のポリオキ シン郕(ポリキャプタン水和剮1,000倍，ポリオキシン 水和郕1,000结) の散布回数は，1〜4回で, 無散布園

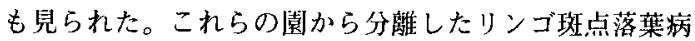
菌217菌株のポリオキシン剂に対する感受性を検定した。 その結果第 3 図に示すように，当地域では栽培年数が浅 いこともあって，感受性菌の占める割合が高く，大部分 の園で高度耐性菌はみられなかったが，1園で34.5\%の 菌株に高度の耐性が認めら扎た。この園では，本年はポ リオキシン剤の散布はなかったものの，昨年はポリオキ シン・キャプタン水和郕を過剩散布していた。また、中

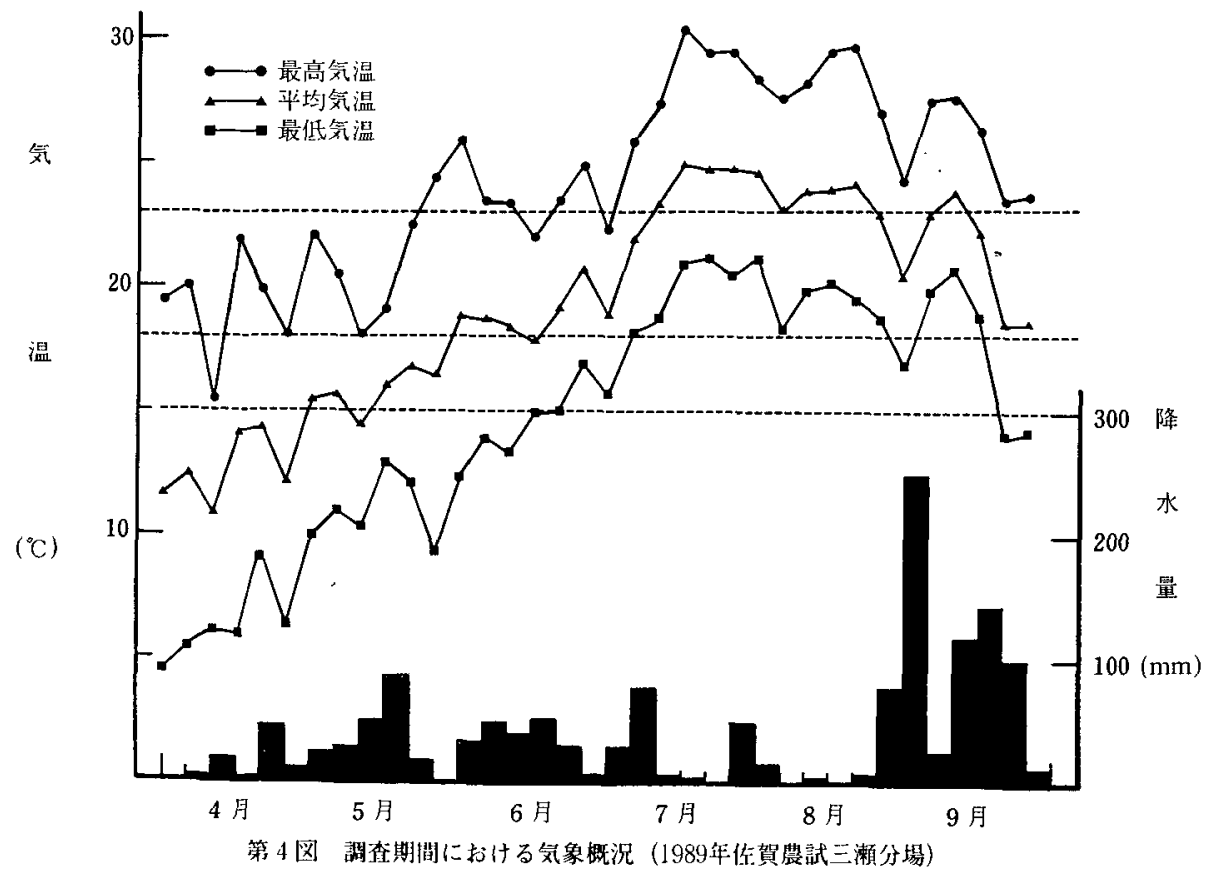


等度耐性菌は11園中大部分の10園で認められれ、このうち， 中等度耐性菌の割合が感受性菌の割合を上回った 2 園で は, 本年度も 3 回以上のポリオキシン・キャプタン水和 剮の散布が行わ扎て㧊り，これらの菌の中にはかなり高 度の耐性菌が多く存在した。

\section{考察}

1989年の調查結果から，佐賀県北部山間地のリンゴ栽 培に扔ける早期落葉の主な原因として斑点落葉病と褐斑 病の両病害が大きく関与していることが明らかになった。 斑点落葉病の発生と気象条件との関係について, 落合 $5^{21}$ は, 最高気温 $23^{\circ} \mathrm{C}$ 以上, 最低気温 $15^{\circ} \mathrm{C}$ 以上, 平均気 温 $18^{\circ} \mathrm{C}$ 以上で発病の增加が誌められ，なかでも最低気温 が $15^{\circ} \mathrm{C}$ 以上になれば急激な発病に結び付き，降水量は多 ければ多いほど発病が增杊する要因となるとしている。 本年の調查では，“ふじに扔いて 6 月上旬以降急激に 発生の増加が認められ，第 4 図の気象表と比較してみる と，落合らの指摘した気像条件と本病の発生との関係は 西南暖地においても一致するのではないかと考元られた。

また，最近，兒地では玟点落葉病の発生がリンゴ導入 初期に比べると增加しているといわれており，その原因 の一つとして本病に卓效を示すポリオキシン剤に対する 耐性菌の出現が考えられた。そこで，本剷に对する感受 性検定を行ったとこう, 高度酎性菌の出現は1園のみで あったが，中等度耐性菌は大部分の園で確認され，その 存在が明らかになった。このことから，今後本剮の使用 回数については充分留意する必要がある。なお，今回用 いた検定法はナシ埋攻病菌 (Alternara alternata Japanese

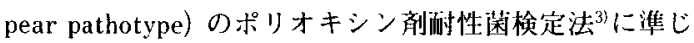
ており，鈴水らが考案したりんご試駼場法りによる検定 方法を含めて，さらに今後検傠していく必要があると思 われる。

品種と発病との関係では，“ふ心゙’は国光”と權病性 品種である ‘デリシャス’との父配種であることから， かなりの罹病性品種とされている。本調査でも、つが るの2 倍以上の発生が観察され，“心じにおいては連 年結果㧍よび樹勢維持のうえで本病防除が最重要課題と いえよう。な拉，今後他の品種についても発生状況を調 查して，暖地に打ける本病の発生実態を明らかにする必 要がある。

褐玟病は 8 月から発病の增玑がみられ，9月に急増し たが、これはつつがるが8月下旬に収檴を迎えること から，農家が農薬散布を控え，また，収權後の防除が打 ろそかになったことによると考えられる。なお、本年の 場合，8月末一9月に降雨が多かったことも発病を助長
した要因であると思われる。本病の発生も落葉を伴うた め，多雨条件下にある当地区に打いては生有中期以降の 重要病害といえる。今後，この時期の防除の元実を図る ことが重要であると考えられる。

黒星病の発生園では, 開花期前後の初期防除の遅れが 激発へつながったものと思われる。幼木園であったため， 果実への影響はなかったが，今後本病の発生については 充分注意する必要があるものと思われる。

害虫については，開花觔からハマキムシ，アブラムシ， さらにはゾウムシ，シャクトリムシの加害があり，被害 も新葉, 花霄, 幼果に及ぶので, 発身10日後, ならびに 開花期前後の防除が必須であろう。その後, 梅雨期には 害虫の発生は少なくなるが，7月下旬以降にアブラムシ， キンモンホソガ，ハマキムシ, シンクイムシの発生がみ られるため，定期的な殺虫剛の散布が必要となる。

なお，以上の結果は1989年のみの成績であり，より正 確な発生消長を把挃し，防除体系の確立によってリンゴ 生産の安定を図るためには，今後も継続的な調查を行っ ていく必要がある。また、リンゴの農薬散布については, さび果，落葉等の薬害が出やすいため，その対策も栽培 現場で急務となっている。

\section{摘 要}

位賀県北部山閒地のリンゴ栽培における早期落葉の主 な原因として、斑点落葉病と褐斑病の而病害が大きく関 与していることが明らかになった。斑点落葉病の発生は, ‘ふじでとくに問題となり, 気温が高くなり, 降雨量 も多くなる 6 月以降に発病の増加が認められた。また, 本病原菌のポリオキシン郕に対する感受性検定を行った ところ，11園中高度耐性菌が 1 園で，中等度耐性菌が10

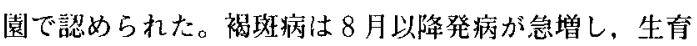
中期以降の重要病害であった。この他, 黑星病, 灰色か び病の発生がみられた。害虫については, 開花期前後に ハマキムシ，アブラムシ，ゾウムシ，シャクトリムシに よる新葉, 花蕾, 約果への加害があり, 7 月下旬以降ア ブラムシ, キンモンホソガ, 八マキムシ，シンクイムシ の発生がみられた。

\section{引用 文献}

1）農林水産省農曋園芸局植物防疫課 農作物有害動植物発生予, 祭事策串施要領（1985）155-176， 2）落合政文・林 重昭 （1972）東北農研 $13: 280-284.3$ 3) 真松光男·御屋秀

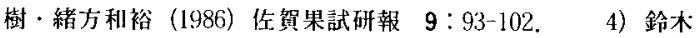
宣健・福島千萬男・田中弥平（1985）青森りんご試報 22： 65-107.

(1990年 4 月24日 受領) 